\title{
HPV Status by PCR
}

National Cancer Institute

\section{Source}

National Cancer Institute. HPV Status by PCR. NCI Thesaurus. Code C159326.

A procedure to determine the HPV status by PCR. 